\title{
SIZE OF AND DAMAGE ON SHOOTS OF PASSIFLORA SUBEROSA (PASSIFLORACEAE) INFLUENCE OVIPOSITION SITE SELECTION OF HELICONIUS ERATO PHYLLIS (FABRICIUS) (LEPIDOPTERA, NYMPHALIDAE)
}

\author{
Elna Mugrabi-Oliveira ${ }^{1}$ \\ Gilson R.P. Moreira ${ }^{2}$
}

\begin{abstract}
Oviposition site selection of Heliconius erato phyllis (Fabricius, 1775) (Lepidoptera, Nymphalidae) was studied when size of and damage on shoots were variable in a natural population of Passiflora suberosa Linnaeus (Passifloraceae), and through sequential and simultaneous choice experiments performed under insectary conditions. Females showed marked oviposition preference for undamaged and largest shoots of $P$. suberosa. Eggs were mostly laid on the terminal buds of intact shoots under natural conditions. In simultaneous choice trials, females preferred to oviposit on shoots from which leaves (ten) were removed but the terminal bud maintained to those where leaves were kept but the terminal bud was cut out. In sequential choice trials, they did not lay eggs on shoots from which the terminal bud was removed. Females preferred to oviposit on large to short intact shoots in both sequential and simultaneous choice trials. Females laid eggs preferentially on shoots with the greatest leaf area when most plants were intact in the field during early spring. Later in fall, when mostly large, old shoots were damaged or in a reproductive stage (less desirable for oviposition), oviposition intensity was highest on the shortest, youngest shoots of $P$. suberosa. Thus, females might rank these quality attributes higher than size while selecting shoots for oviposition. The consequences of ovipositing selectively on intact, large shoots of $P$. suberosa are discussed from the view point of $H$. erato phyllis larval performance.

KEY WORDS. Lepidoptera, Heliconius, Passiflora, oviposition behavior, host plant selection
\end{abstract}

Plant characteristics have been shown to influence many herbivorous insect. in terms of host preference for oviposition. While selecting hosts for oviposition, oligophagous insects usually discriminate between different host plant species (WikLund 1975, 1981; SINGER 1986; BERNAYS \& ChAPMAN 1994). Their discrimination may be also strongly affected by variation within individual plants (JONES 1991; BERNAYS \& CHAPMAN 1994 ), which may not necessarily be overridden by host plant species effects. On the contrary, host-choice based on host species may

1) Pós-graduação em Entomologia, Departamento de Zoologia, Universidade Federal do Paraná. Caixa Postal 19020, 81531-990 Curitiba, Paraná, Brasil.

2) Correspondence to: Departamento de Zoologia, Instituto de Biociências, Universidade Federal do Rio Grande do Sul. Avenida Paulo Gama 40, 90046-900 Porto Alegre, Rio Grande do Sul, Brasil.

e-mail: grpm@if.ufrgs.br 
be less important than on host choice based on intraspecific plant attributes, in those insects that specialize on plant individuals or tissues in a particular phenological category (e.g. CATES 1980; LEWIS 1982; THOMAS 1987). Such insects might not show preference for a particular host species, and as suggested by THOMAS (1987), may still have as narrow a diet as a monophagous species that feeds on many plant tissues.

Passion vine butterflies (Nymphalidae: Heliconiinae) are associated with a narrow range of host plants in a given location as has been observed throughout the neotropics (see BENSON et al. 1976; BROWN 1981; GILBERT 1991). Oviposition preference within the range of host plants of some oligophagous heliconiine has also been experimentally demonstrated (COPP \& DAVENPORT 1978; SMILEY 1978; MENNA-BARRETo \& ARAúJo 1985; PERICO \& ARAúJo 1991). In addition, field observations have strongly suggested that larvae of most passion vine butterflies feed preferentially on particular parts of their host plants, and that these are chosen for oviposition (see ALEXANDER 1961; BENSON et al. 1976; BENSON 1978). That heliconian butterflies select hosts for oviposition based upon qualitative attributes of these preferred plant parts has been also suggested (BENSON et al. 1976; BENSON 1978). However, little experimental work has been reported on the influence of intraspecific variation of passion vine attributes on oviposition behavior of these butterflies. Field observations carried out by LOPES (1991) suggest Heliconius erato (Linnaeus, 1758) females choose for oviposition shoots with "fast" over "slow" growth meristem in passion vine populations of Serra do Japi, São Paulo.

The work reported here is part of a more general study concerning the influence of host plant characteristics on oviposition site selection behavior of Heliconius erato phyllis (Fabricius, 1775), a common butterfly in southern Brazil (BROWN \& MIELKE 1972). H. erato phyllis is oligophagic in Rio Grande do Sul State (RS), eggs and larvae being found primarily on Passiflora suberosa Linnaeus, in areas where this passion vine predominates (PERICO \& ARAÚJO 1991). Passiflora suberosa is in fact one of the most abundant passion vines occuring in RS, but it is not the most preferred for oviposition or most suitable as food for $H$. erato phyllis larvae, as judged by laboratory studies (MENNA-BARRETO \& ARAÚJO 1985; PÉRICO \& ARAújo 1991). Thus, it is suspected that use of $P$. suberosa over other more preferred or more suitable host plants for larvae (e.g. P. misera Humboldt, Bonpland $\&$ Kunth and $P$. elegans Masters) may be mediated at local basis by variation intrinsic to these host plant populations, such as their relative availability and phenology (see CATES 1980; SOLOMON 1981; COURTNEY \& FORSBERG 1988), or due to variation in preference of females within populations (see WIKLUND 1981; PAPAJ \& RAUSHER 1983; ARAÚJO 1987; JONES 1991). In the present study, it is addressed this question by determining $H$. erato phyllis ovipositional response to variation in size of and damage to host plants, based upon samples taken in a natural population of $P$. suberosa and on ovipositional choice experiments carried out under insectary conditions. 


\section{MATERIALS AND METHODS}

\section{Study Site and Sample Procedure}

Field studies were conducted on a Passiflora suberosa population in the Águas Belas Experimental Station (FEPAGRO), Viamão County, RS, from November 1, 1994 to May 1, 1995. Shoot samples were taken along an approximately $2 \mathrm{~m}$ wide and $200 \mathrm{~m}$ long trail, located in an Eucalyptus-plantation. The vegetation was characterized by a patchy native flora mixed with Eucalyptus-trees. P. suberosa predominates in the herbaceous stratum, at some places covering totally the trail ground. Other Passiflora vines were sparsely found in the area, including $P$. misera, $P$. elegans, $P$. caerulea Linnaeus, $P$. alata Dryander and $P$. edulis Sims.

Samples were taken at 45-day intervals, fifty on each date. Sampling points were randomly selected and identified by stretching a tape measure on the trail. Then, P. suberosa shoots located nearest to sorted positions were cut out and individually placed in plastic bags. A pilot study showed that $H$. erato phyllis eggs occur at very low densities in the area, which would make comparison difficult between plants with and without eggs within samples. To make such comparison possible, all P. suberosa plants located along the trail were concurrently inspected, and those shoots bearing $H$. erato phyllis eggs were also collected, until a number of ten to be reached on each date. In the laboratory, all shoots were carefully examined for the presence of other insect eggs and larvae, and classified according to their phenology and presence of intact terminal bud (made up of apical meristem, leaf primordia and overlapping leaves) (Fig. 1A). Those shoots where the terminal bud was absent, wilted or dried up, were considered as "damaged" (Fig. 1B,C). Then, shoots were pressed, air dried and their leaf area determined with a Li-Cor ${ }^{B}$ portable leaf area meter.

\section{Plants and insects}

Passiflora suberosa plants $(\mathrm{n}=70)$ used in the oviposition choice tests were transplanted at a very early developmental stage from the field study area into 3.8-liter pots, and grown in a large outdoor screened cage. Pots were provided with $50 \mathrm{~cm}$ high wooden frame supports for shoot growth.

Heliconius erato phyllis females used in the ovipositional choice trials were collected in Porto Alegre County, RS. They were wing marked with an felt-tip pen $\left(\mathrm{Pilot}^{(\mathbb{R}}\right)$, and maintained in a $2.6 \times 4.5 \times 5.6 \mathrm{~m}$ outdoor screened insectary, located at the Zoology Department of Federal University of Rio Grande do Sul State, Porto Alegre. Females were fed twice a day (early morning and afternoon) with a mixture of $7.5 \mathrm{~g}$ sucrose, $1.5 \mathrm{~g}$ commercially available honey bee-pollen $\left(\mathrm{AGA}^{\circledR}\right)$ and distilled water $(50 \mathrm{ml})$. The solution was placed in yellow sponges set on small, red color, plastic vials. To resemble natural conditions, the insectary was provided with non host-plants (mostly Impatiens balsamina Linnaeus, Lantana camara Linnaeus, Euphorbia pulcherrima Willdenow ex Klotzsch, Monstera deliciosa Liebm. and an unidentified Pilea Lindley species). A few potted $P$. suberosa plants were offered for oviposition. Eggs were removed from plants during daily inspections. As already noted for other Heliconius populations that were maintained under similar insectary 
conditions (e.g. GILBERT 1972), behavior and oviposition rates (averaged over 3 eggs/individual/day) among kept females were apparently identical to that of wild individuals. To control for variation among individuals, females were randomly selected, and never used in consecutive days or more than two times in a given test. Dead or senescent females (indicated by wing-scale loss, or low ovipositon rate during the tests) were replaced accordingly throughout the experimental period.
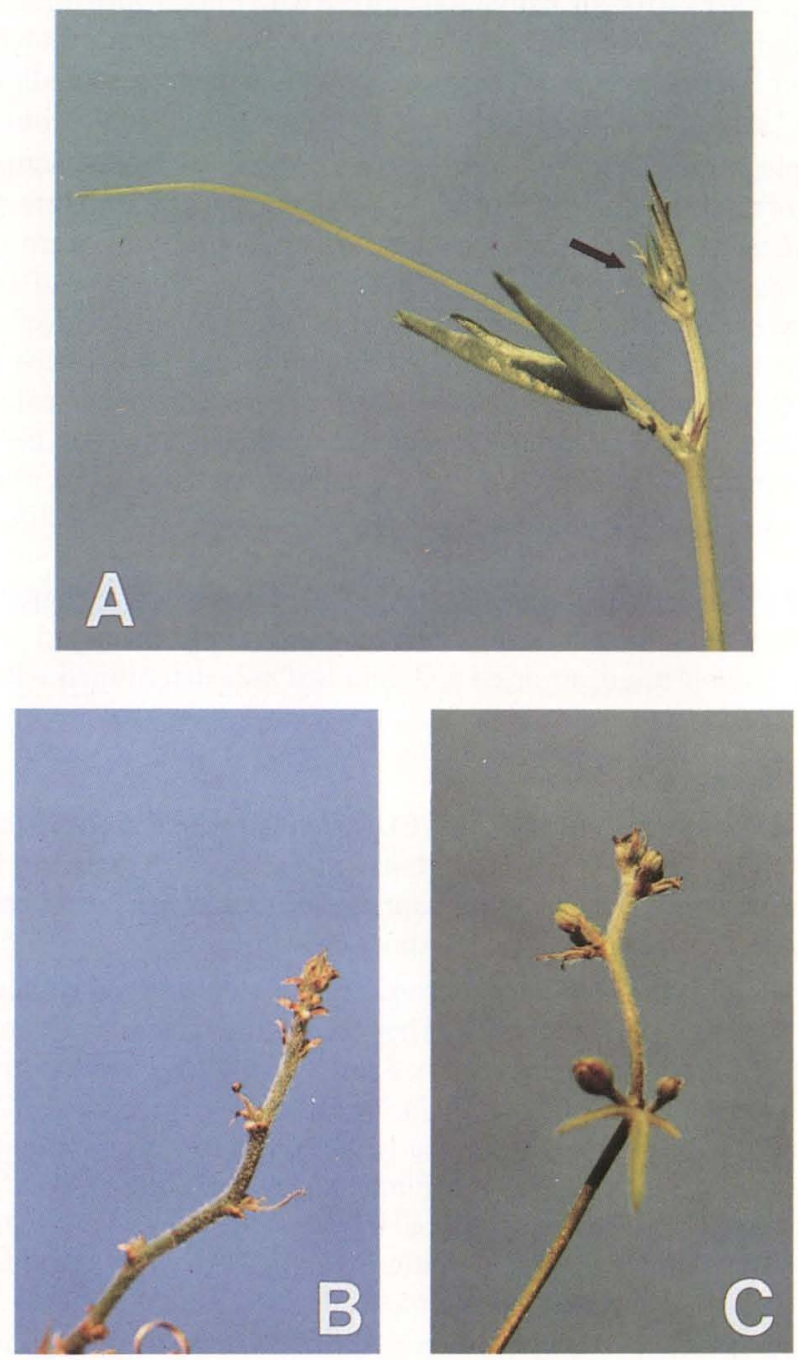

Fig. 1. Terminal portion of $P$. suberosa shoots. (A) With intact terminal bud (arrow), (B-C) with damaged terminal bud. 


\section{Ovipositional choice experiments}

Trials were conducted from December 1994 to March 1995, in an adjacent outdoor insectary $(2.0 \times 6.0 \times 1.8 \mathrm{~m})$ equivalent to that described previously (including non-host plants).

Sequential and simultaneous choice trials (sensus SINGER 1986) were performed to determine the relative importance of presence of terminal buds and size of $P$. suberosa shoots in relation to oviposition site selection of $H$. erato phyllis. Three shoot types (= treatments) were used for evaluating effects related to the presence of terminal buds: 1) with ten leaves and terminal bud; 2) with leaves removed and terminal bud kept; 3 ) with ten leaves and terminal bud cut out (Fig. 2). Three treatments were also used for testing shoot size effects: 1) large shoots $40 \mathrm{~cm}$ long, with ten leaves (B + L, Fig. 2); 2) medium - 30 cm long, with seven leaves; 3 ) small $-15 \mathrm{~cm}$ long, with three leaves. Plants were standardized for size by removing extra tissue, the main shoot being the only one left in each pot prior to using plants in the tests. H. erato phyllis eggs were laid individually on $P$. suberosa plants under field conditions, in an expected daily oviposition rate varying from 3 to 5 eggs per female (DUNLAP-PIANKA et al. 1977). Due to these aspects, a ratio of five plants per female was used for all treatments in the experiments.

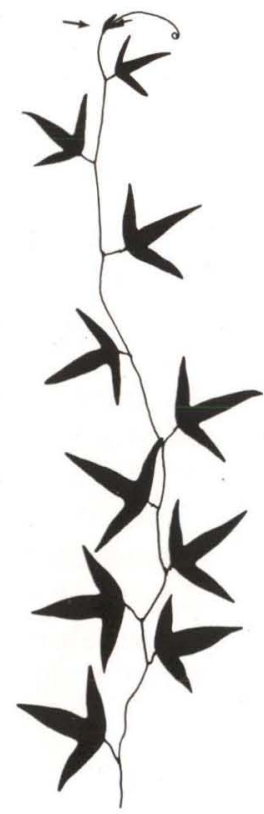

$\mathbf{B + L}$

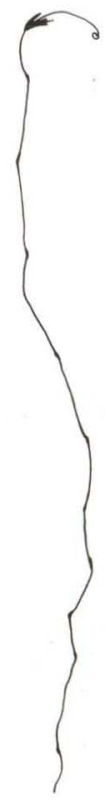

B

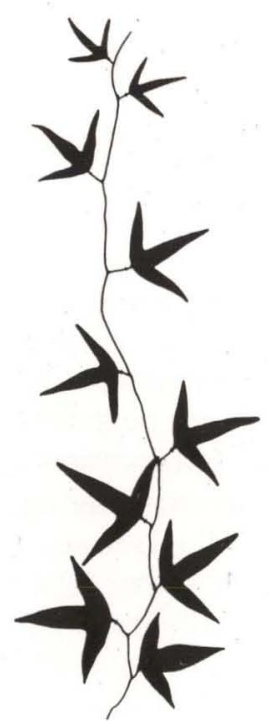

$\mathbf{L}$

Fig. 2. Schematic representation of $P$. suberosa shoots used in the ovipositional choice experiments. $(B+L)$ With ten leaves and terminal bud (arrow); $(B)$ with leaves removed and terminal bud kept; (L) with ten leaves and terminal bud cut out. To facilitate visualization, tendrils and stipules associated with open leaves were not included. 
A diel oviposition profile determined for $H$. erato phyllis prior to this study showed that most oviposition acitivity occurs from 8 a.m. to 5 p.m., thus tests were conducted during this time interval. In the simultaneous choice trials, all shoot types were introduced simultaneously in the insectary, and the oviposition response was quantified through the entire experimental period ( 9 hours each day). For the sequential choice trials, the experimental period was divided intro three $3 \mathrm{~h}$-intervals; the insectary was divided by nylon screens into three $3-\mathrm{m}$ sections, where shoots were distributed according to type. Females were moved among sections at the end of these pre-determined intervals during the tests.

Only one female was tested each day, and each experiment lasted for 20 days (= number of replicates). Plants were carefully inspected for egg deposition at the end of each period, when eggs were counted and removed. Females, plants, pot position in the insectary and order of treatment to be tested in a given day in the sequential choice trials were all randomized.

Results from ovipositional choice experiments were expressed as average daily oviposition rates per female ( \pm standard errors), unless noted. Data were log transformed for the analysis of variance, following criteria described in SOKAL \& ROLHF (1981). Where analyses of variance were significant, differences among treatments were tested using Tukey multiple comparison tests, alpha $=0.05$. Non-parametric statistical tests followed procedures described in SIEGEL (1956).

\section{RESULTS}

\section{Field studies}

There was considerable variation in number of shoots with intact terminal buds and plant phenology in the P. suberosa population among samples. From a total of 246 collected shoots, 174 (70.75\%) had undamaged terminal buds. Proportion of shoots with intact terminal buds decreased from $87.23 \%$ at the first sample (spring) to $36.0 \%$ on the last sample date (fall) (Fig. 3A). Reproductive structures (flowers or fruits) were present in $63(25.61 \%)$ of the total collected shoots. Contrary to trend noted for terminal bud damage, proportion of shoots with reproductive structures increased progressively from $14.9 \%$ at the first sample (November) to $44.0 \%$ in April, and decreased again in the last sample taken in early May (Fig. 3B).

The inspections for egg deposition performed in the P. suberosa plants located along the trail showed that females oviposited exclusively on intact terminal portion of shoots. From a total of 43 shoots that were collected with eggs, $25(60 \%)$ had them located on the terminal buds. In the remaining egg-bearing shoots, they were found on open leaves and tendrils located near the terminal bud (Fig. 4).

There was great variation in leaf area among shoots in the $P$. suberosa population. It ranged from 2.84 to $463.5 \mathrm{~cm}^{2}$ among collected shoots (average of $83.71 \pm 74.51 \mathrm{~cm}^{2}$ per shoot). There was no indication that average leaf area of shoots varied among sample dates in the population (Fig. 5). There was also pronounced variation in leaf area among egg-bearing shoots. Eggs were laid on shoots with leaf area varying from 5.58 to $463.5 \mathrm{~cm}^{2}$ (average of $120.36 \pm 82.72 \mathrm{~cm}^{2}$ ). The average 
size of egg-bearing shoots decreased progressively throughout field evaluations. As indicated by the first two samples, females selected shoots for oviposition that had greater leaf area than the average in the population during later spring. However, in the last sample, during early fall, they chose shoots with lower leaf area than the population in average (Fig. 5). Although data were not included here, total length and number of leaves per shoot decreased in a similar way to leaf area through the experimental period (E. Mugrabi-Oliveira unpublished data).

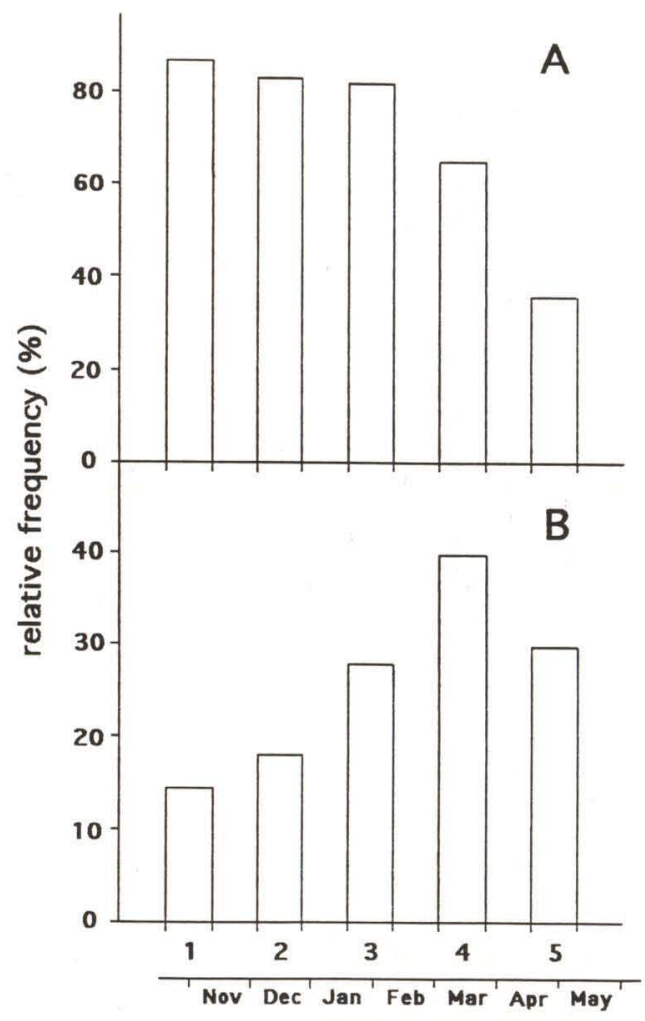

Fig. 3. Seasonal variation in number of $P$. suberosa shoots with undamaged terminal buds $(\mathbf{A})$ and under reproductive stage (B) at Águas Belas Experimental Station, Viamão County, Rio Grande do Sul, 1994/95. Numbers from 1 to 5 represent 45-day sample intervals.

\section{Ovipositional choice tests}

Presence of terminal buds on $P$. suberosa shoots significantly affected $H$. erato phyllis oviposition site selection in the insectary experiments. In the simultaneous choice trials, there was no oviposition on shoots from which terminal buds were cut out. Also, oviposition intensity was significantly greater on shoots bearing ten leaves and terminal bud than those where only the terminal buds were kept (Fig. $6 \mathrm{~A})$. In the sequential choice trials, oviposition on shoots without terminal buds was 
lower than those with ten leaves and terminal buds or terminal buds only (Fig. 6B). There was also a significant shoot size effect on oviposition site selection. Oviposition intensity significantly decreased with a decrease in shoot size in the simultaneous choice trials (Fig. 7A). Females laid eggs on small plants at significantly lower intensity than in medium or large size plants in the sequential choice trials (Fig. 7B).

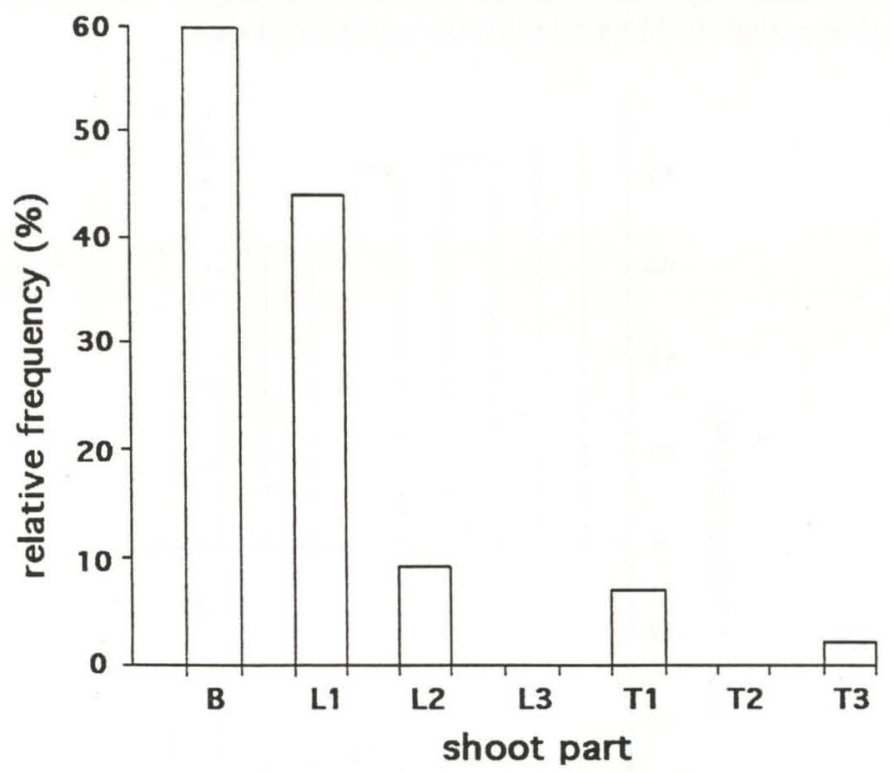

Fig. 4. Parts of $P$. suberosa shoots used for oviposition by $H$. erato phyllis at Águas Belas Experimental Station, Viamão County, RS, 11/1/94-5/1/95. (B) Terminal bud; (L) open leaf, (T) tendril; (1-3) position in relation to shoot apex.

\section{DISCUSSION}

Both field and insectary results from this study showed that presence of intact terminal bud is an important factor in determining selection of a given $P$. suberosa shoot for oviposition by $H$. erato phyllis. In accordance with LOPES (1991) observations for a $H$. erato phyllis population of Serra do Japi, São Paulo State, eggs are only found on the subterminal portion of P. suberosa shoots at Águas Belas Experimental Station. Young leaves have been recognized as the preferable oviposition site of $H$. erato for a number of Passiflora vines (CRANE 1955; ALEXANDER 1961; BENSON 1978; LOPES 1991). Our field results further demonstrated that intact $P$. suberosa shoots are preferred to those with damaged terminal buds, thus adding evidence to the suggestion made by BENSON (1978) in that H. erato phyllis females evaluate host plant quality before oviposition. The simultaneous and sequential choice trials performed in this study showed that females reject to oviposite on shoots from which terminal buds were cut out. They also indicated that females recognize shoot size, preferring the largest shoots for oviposition. 


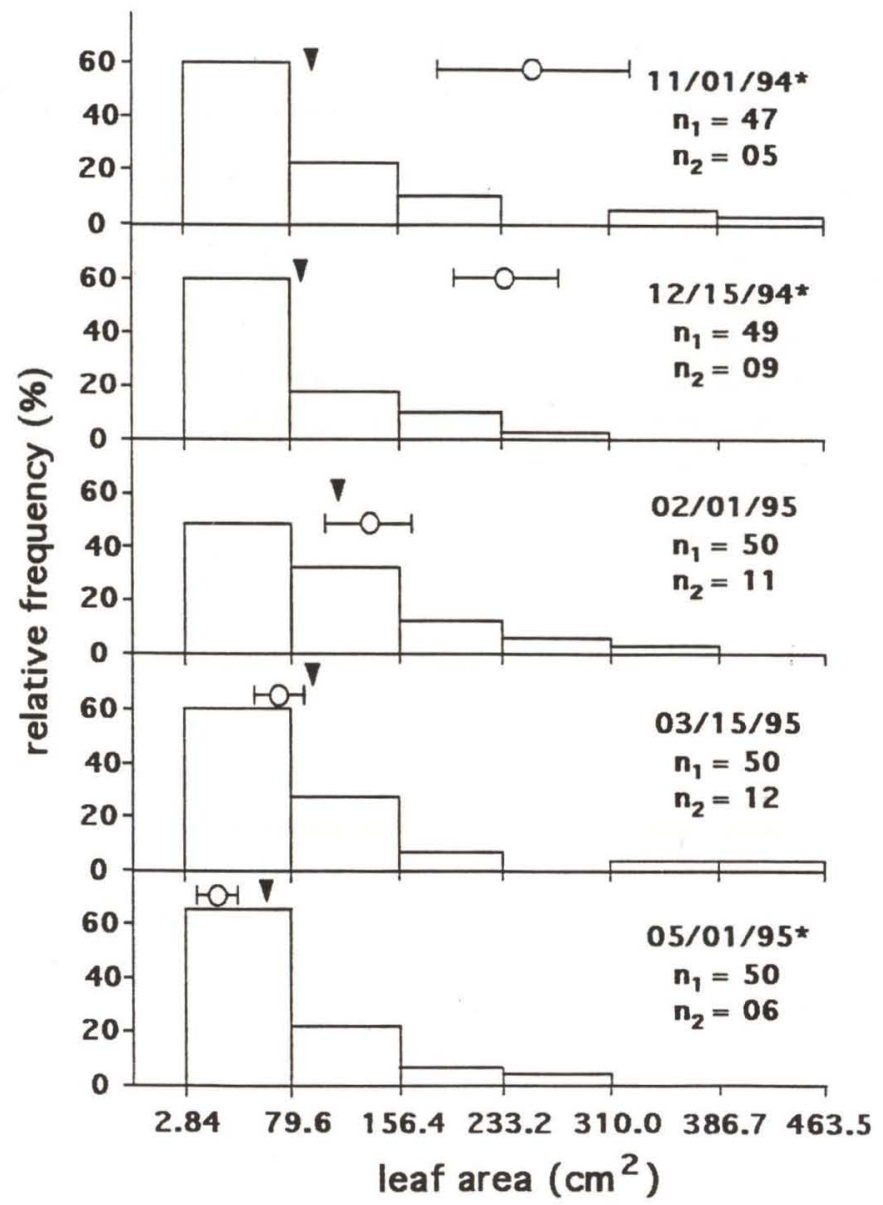

Fig. 5. Seasonal variation in leaf area on shoots of $P$. suberosa at Águas Belas Experimental Station, Viamão County, RS, $1994 / 95$. The average leaf area of the total collected shoots $\left(\mathbf{n}_{1}\right)$ is indicated by closed triangles. Open circles and associated bars indicate the average leaf area ( \pm standard error) of shoots bearing eggs $\left(\mathbf{n}_{2}\right)$ of $H$. erato phyllis. Asterics indicate significant statistical difference in leaf area between shoots with and without eggs (Mann-Whitney $U$, one-tailed test, alpha $=0.05$ ).

It has been inferred from other studies that evolution of plant species preference among oligophagous insects is shaped at least in part by plant suitability as larval food (e.g. WIKLUND 1975; SINGER 1983; LEATHER 1985; HAMILTON \& ZALUCKI 1993a,b). Similarly, it is expected that preference for oviposition on a given plant part to be also related to suitability of the corresponding tissue as larval food. Results from preliminary studies carried out in our laboratory (D. Rodrigues and G.R.P. Moreira unpublished data) strongly suggest that choice of $H$. erato phyllis females for oviposition on intact, new growing shoots of $P$. suberosa has important consequences on larval survival and growth rates. First and second instar 
larvae when tranferred to $P$. suberosa shoots having only old leaves have reduced survivorship probability ( 30 and $60 \%$, respectively), when compared to those reared since the beginning on intact shoots with terminal bud (100\% of survivorship). Transference of the first two larval instars to old leaves also leads to a significant delay in larval development. On the other hand, there is no effect on survivorship and growth rates of larvae when they are initially reared on intact leaves and then transferred at third, fourth, or fifth instars to old leaves. Thus, the presence of young leaves is crucial for success of early larval instars of $H$. erato phyllis, and may constitute the natural selection mechanism by which the behavior of laying eggs on intact, subterminal portion of $P$. suberosa shoots is maintained in the population (D. Rodrigues and G.R.P. Moreira unpublished data).

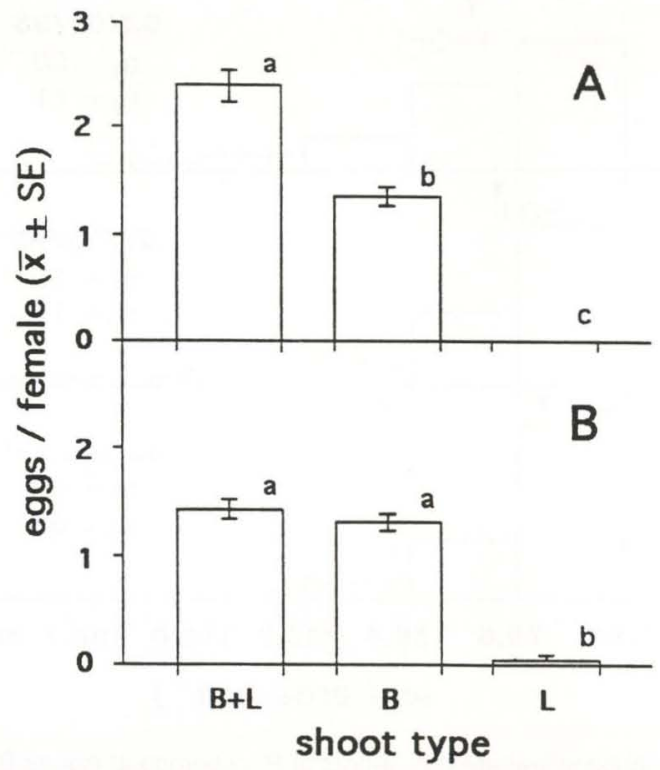

Fig. 6. Egg-laying response of $H$ erato phyllis to variation in $P$. suberosa shoot structure in simultaneous $(A)$ and sequentail $(B)$ choice trials. $(B+L)$ With ten leaves and terminal bud; (B) with leaves removed and terminal bud kept; (L) with ten leaves and terminal bud cut out. Values followed by the same letter are not significantly different (Anova, alpha $=0.05$; Tukey multiple comparison tests, alpha $=0.05$ ).

The first results obtained from another study in progress at our laboratory indicate that size of shoots chosen for oviposition might also influence $H$. erato phyllis larval development. When fed with $P$. suberosa leaves, this species needs to consume from 105.5 to $205.92 \mathrm{~cm}^{2}$ (average of $148.58 \mathrm{~cm}^{2}$ ) of leaf area for completion of the larval stage (C.A. Barcellos and G.R.P. Moreira unpublished data). At any given time for the $P$. suberosa population sampled in the present study, total leaf area of more than half of shoots was lower than that required for larval development of $H$. erato phyllis. From a natural selection perspective, it would be expected that given a choice, females should lay eggs on those shoots with the 
greatest leaf area, to ensure a satisfactory development for offspring. In the present study, such a response was observed in the first two field samples and on both simultaneous and sequential choice trials. Nevertheless, females laid eggs on shoots with leaf area lower than the average in the P. suberosa population in the last two samples. It is supposed that in such cases larvae starve before pupation, or find another suitable shoot for feeding. However, such nutritional and behavioral consequences of laying eggs on shoots with lower leaf area than that required for larval development remains to be tested for $H$. erato phyllis. BENSON et al. (1976) inferred eventual starvation for some individuals of $H$. erato, as judged by the presence of adults with reduced size found in insect collections. Larvae of another specialized young leaf feeder, Heliconius hewitsoni Staudinger starve before pupation when eggs are laid on short shoots of Passiflora pittieri Masters in Costa Rica (DUCKETT 1989).

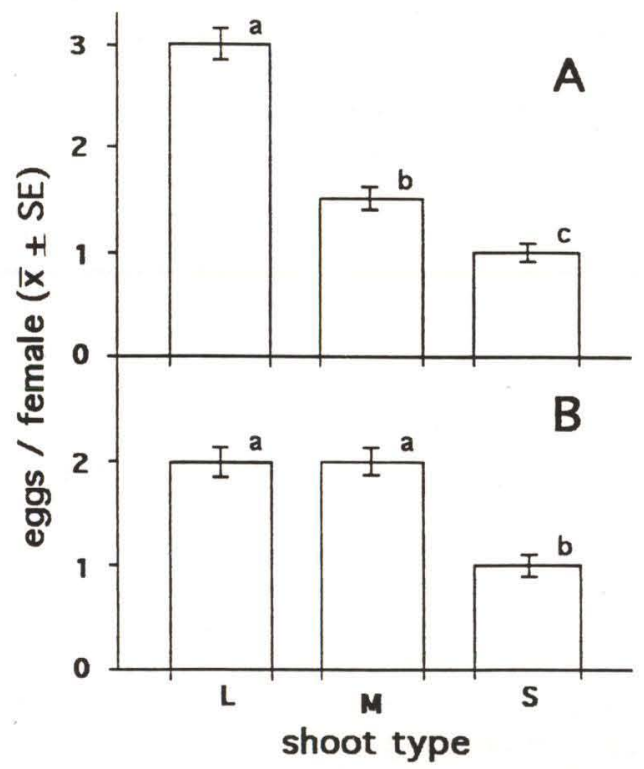

Fig. 7. Egg-laying response of $H$. erato phyllis to variation in $P$. suberosa shoot size in simultaneous (A) and sequential (B) choice trails. (L) Large, with ten leaves and $40 \mathrm{~cm}$ long; (M) medium, with seven leaves and $30 \mathrm{~cm}$ long; (S) small, with three leaves and $15 \mathrm{~cm}$ long. Values followed by the same letter are not significantly different (Anova, alpha $=0.05$; Tukey multiple comparison tests, alpha $=0.05$ ).

Since there was not oviposition on damaged shoots, it is supposed that qualitative attributes might be more important than size as criteria to choose shoots for oviposition by $H$. erato phyllis. Thus, the progressive decrease in size of those shoots that were selected for oviposition could have resulted first from the concurrent decrease in number of intact shoots available in the $P$. suberosa population throughout the experimental period. Damage on shoots were mainly due to insect feeding, including unidentified flea beetles (Coleoptera, Chrysomelidae), larvae 
from notodontid moths and other passion vine butterflies besides $H$. erato phyllis. Second, the size decrease of shoots choosen for oviposition could also be related to changes in phenology of $P$. suberosa plants. That is, females probably prefer to lay eggs on vegetative rather than reproductive stage plants. From the 43 shoots collected with eggs, only four (6.98\%) were in reproductive stage (flowers present); the number of these shoots increased progressively in the population up to the end of summer. Thus, the shortage of plants in appropriate phenological category could also be important in forcing females to choose for oviposition the smallest, new growing shoots during early fall. It is suspected that $H$. erato phyllis oviposition on shoots with "fast" growth meristem in preference to "slow", reported by LOPES (1991), may result from these phenology changes on P. suberosa plants. Preliminary observations made (G.R.P. Moreira unpublished data) suggest shoots of $P$. suberosa grow in a similar way to that described by LONGINO (1984) for $P$. pittieri in Costa Rica. At the beginning, shoot elongation rate is high, it levels off as shoots leaf out, and apparently growth is reduced with the start of reproduction. Choice tests using shoots under vegetative and reproductive stages should be conducted in the future to better evaluate the influence of plant phenology on $H$. erato phyllis oviposition site selection.

It has been demonstrated that insect host plant use is influenced by at least three other major component, besides host suitability: insect host finding behavior and preference, and density of potential hosts (JAENIKE 1978, 1990; SOLOMON 1981; WIKLUND 1981; SINGER 1983, 1986; COURTNEY \& FORSBERG 1988; JONES 1991). It is showed experimentally in this study that $H$. erato phyllis lays eggs only on the terminal portion of $P$. suberosa shoots, and that intraspecific variation in host plant attributes, such as damage and size of shoots, influences host selection for oviposition. Thus, a two component form of discrimination based on both withinand between-plant species attributes may hold for $H$. erato phyllis, as has been suggested for other oligophagous insects (e.g. THOMAS 1987). In other words, if within the host plant species range, $H$. erato phyllis chooses suitable shoots for oviposition irrespective of which species those shoots come from, it is expected that field distribution of eggs and larvae will be influenced by the relative abundance of these host plant species. H. erato phyllis uses a relative wide number of Passifloraspecies as hosts, and although it was not yet experimentally tested, differences on host plant species use have been recognized for a number of southeastern Brazilian populations of this passion vine butterfly (BENSON et al. 1976). In Rio Grande do Sul State, local variation in distribution of $H$. erato phyllis eggs and larvae among Passiflora species seems to reflect the relative abundance of the most preferred and suitable host plants (P. misera, $P$. capsularis Linnaeus, $P$. suberosa, $P$. elegans), judging by field data provided by MENNA-BARRETO \& ARAÚJO (1985), PÉRICO \& ARAÚJO (1991) and LUTZ (1995), and observations made in the present study. We are now carrying out a more detailed investigation concerning the underlying mechanisms of oviposition host selection in $H$. erato phyllis, using different densities of $P$. misera and $P$. suberos $a$ as hosts, to examine in particular choice based on plant variation compared to that on host species. 


\begin{abstract}
ACKNOWLEDGMENTS. Thanks are due to FEPAGRO for allowing us to carry out the study at Águas Belas Experimental Station. We are especially grateful to Aldo M. Araújo for encouraging and helping us to start with Heliconius-Passiflora studies. We also thank Miriam Becker for some advice on sampling techniques, and Feliciano Flores for the use of the leaf area meter. Comments by Catherine N. Duckett (University of Puerto Rico), Nicoleta T.N. Sabetzki (EPAGRI) and Aldo M. Araújo (UFRGS) improved earlier versions of the manuscript. Financial support for this study came from a CNPq Schoolarship (M.Sc. Thesis) granted to E. Mugrabi-Oliveira.
\end{abstract}

\title{
REFERENCES
}

ALEXANDER, A.J. 1961. A study of the biology and behavior of the caterpillars, pupae and emerging butterflies of the subfamily Heliconiinae in Trinidad, West Indies. Part I. Some aspects of larval behavior. Zoologica 46: 1-24.

ARAÚJo, A.M. 1987. Teoria dos jogos e estratégias evolutivamente estáveis. Actas .XVII Congresso Argentino de Genética, Rio Cuarto, p.27-33.

BENSON, W.W. 1978. Resource partitioning in passion vine butterflies. Evolution 32: 493-518.

BENSON, W.W.; K.S. BROWN JR. \& L.E. GILBERT. 1976. Coevolution of plants and herbivores: passion flower butterflies. Evolution 29: 659-680.

BERNAYS, E.A. \& R.F. CHAPMAN. 1994. Host-plant selection by phytophagous insects. Chapman \& Hall, 312p.

BRown JR., K.S.. 1981. The biology of Heliconius and related genera. Ann. Rev. Entomol. 26: 427-456.

BRown JR., K.S. \& O.H.H. MielKE. 1972. The heliconians of Brazil (Lepidoptera: Nymphalidae). Part II. Introduction and general comments, with a supplementary revision of the tribe. Zoologica 57:1-40.

CATES, R.G. 1980. Feeding patterns of monophagous, oligophagous, and polyphagous insect herbivores: the effect of resource abundance and plant chemistry. Oecologia 46: 22-31.

Copp, N.H. \& D. DAvenport. 1978. Agraulis and Passiflora I. Control of specificity. Biol. Bull. 155: 98-112.

COURTNEY, S.P. \& J. FORSBERG. 1988. Host use by two pierid butterflies varies with host density. Func. Ecol. 2: 67-75.

CRANE, J. 1955. Imaginal behavior of a Trinidad butterfly, Heliconius erato hydara Hewitson, with special reference to the social use of color. Zoologica 40: 167-195.

DUCKETT, C.N. 1989. Natural history of Pedilia sp. A and its interactions with other herbivores of Passiflora pittieri. Entomography 6: 381-389.

DunLAP-PIANKA, H.L; C.L. BogGS \& L.E. GiLBERT. 1977. Ovarian dynamics in Heliconiine butterflies: programmed senescence versus eternal youth. Science 197: 487-490.

GILBERT, L.E. 1972. Pollen feeding and reproductive biology of Heliconius butterflies. Proc. Nat. Acad. Sci. 69: 1403-1407. 
GILBERT, L.E. 1991. Biodiversity of a Central American Heliconius community: pattern, process, and problems, p.403-427. In: P.W. PRICE; T.L. LEWINSOHN; G.W.FERNANDES \& W.W. BENSON (Eds). Plant-Animal Interactions: evolutionary ecology in tropical and temperate regions. John Wiley \& Sons.

HAMILTON, J.G. \& M.P. ZALUCKI. 1993a. Interactions between a specialist herbivore, Crocidosema plebejana, and its host plants Malva parviflora, and cotton, Gossypium hirsutum: larval performance. Entomol. exp. appl. 66: 199-205.

HAMILTON, J.G. \& M.P. ZALUCKI. 1993b. Interactions between a specialist herbivore, Crocidosema plebejana, and its host plants Malva parviflora, and cotton, Gossypizm hirsutum: oviposition preference. Entomol. exp. appl. 66: 207-212.

LoNGINO, J.T. 1984. Shoots, parasitoids, and ants as forces in the population dynamics of Heliconius hewitsoni in Costa Rica. Unpublished Ph.D. Dissertation, University of Texas, Austin.

JAENIKE, J. 1978. On optimal oviposition behavior in phytophagous insects. Theor. Popul. Biol. 14: 350-356.

1990. Host specialization in phytophagous insects. Annu. Rev. Ecol. Syst. 21: 243-73.

JONES, R.E. 1991. Host location and oviposition on plants, p.139-171. In: W.J. BAILEY \& J. RIDSDILl-SMith (Eds). Reproductive behavior of insects: individuals and populations. Chapman \& Hall.

LEATHER, S.R. 1985. Oviposition preferences in relation to larval growth rates and survival in the pine beauty moth, Panolis flammea. Ecol. Entomol. 10: 213-217.

LEWIS, A.C. 1982. Leaf wilting alters a plant species ranking by the grasshopper Melanoplus differentialis. Ecol. Entomol. 7: 391-395.

LOPES, F.S. 1991. Padrões sazonais e evolução do uso de plantas hospedeiras de larvas por Heliconius erato phyllis (L.) (Lepidoptera, Nymphalidae) na Serra do Japi, São Paulo. Unpublished Ph.D. Dissertation, Instituto de Biologia, Universidade Estadual de Campinas, Campinas, 119p.

LUTZ, L.V. 1995. Variação e seleção sobre o padrão de coloração das asas de Heliconius erato phyllis (Lepidoptera; Nymphalidae) em populações naturais. Unpublished M.Sc. Thesis, Instituto de Biociências, Universidade Federal do Rio Grande do Sul, Porto Alegre, 76p.

MENNA-BARRETO, Y. \& A.M. ARAÚJO. 1985. Evidence for host plant preferences in Heliconius erato phyllis from southern Brazil (Nymphalidae). J. Res. Lepid. 24: 41-46.

Mugrabi-Oliveira, E \& G.R.P. Moreira. 1996. Conspecific mimics and low host plant availability reduce egg laying by Heliconius erato phyllis (Lepidoptera, Nymphalidae). Revta bras. Zool. 13 (4): 929-937.

PAPAJ, D.R. \& M.D. RAUSHER. 1983. Individual variation in host location by phytophagous insects, p.77-124. In: S. AHMAD (Ed.) Herbivorous insects: host- seeking behavior and mechanisms. Academic Press.

Perico, E. \& A.M. ARAúJo. 1991. Suitability of host plants (Passifloraceae) and 
their acceptableness by Heliconius erato and Dryas iulia (Lepidoptera; Nymphalidae). Evol. Biol. 5: 59-74.

SIEGEL, S. 1956. Nonparametric statistics: for the behavioral sciences. Freedman and Company.

SINGER, M.C. 1983. Determinants of multiple host use by a phytophagous insect population. Evolution 37: 389-403. 1986. The definition and measurement of oviposition preference in plantfeeding insects, p.65-94. In: J. MILLER \& T. MILLER (Eds). Insect-plant interactions. Springer-Verlag.

SMILEY, J. 1978. Plant chemistry and the evolution of host specificity: new evidence from Heliconius and Passiflora. Science 201: 745-747.

SOKAL, R.R. \& F.J. ROHLF. 1981. Biometry. W.H. Freeman and Company, $2^{\text {nd }}$ ed.

SolOMON, B.P. 1981. Response of a host-specific herbivore to resource density, relative abundance, and phenology. Ecology 62: 1205-1214.

THOMAs, C.D. 1987. Behavioural determination of diet breadth in insect herbivores: the effect of leaf age on choice of host species by beetles feeding on Passiflora vines. Oikos 48: 211-216.

WiKLUND, C. 1975. The evolutionary relationship between adult oviposition preferences and larval host plant range in Papilio machaon L. Oecologia 18: 185-197.

1981. Generalist vs. specialist oviposition behaviour in Papilio machaon (Lepidoptera) and functional aspects on the hierarchy of oviposition preferences. Oikos 36: 163-170. 